\title{
Scribes and Dialects in Late Bronze Age Canaan
}

\author{
Juan-Pablo Vita \\ CSIC-IEIOP, Zaragoza
}

\section{Language, dialects and scribes in the Syro-Palestinian Amarna letters}

1.1. The Syro-Palestinian Amarna letters (= EA) have a multiple linguistic interest. ${ }^{1}$ The language used in the 14th century B. C. in the letters from the Syro-Palestinian vassals from Egypt, known as "Canaanite" (cf. Rainey 1996; von Dassow 2004) or "Canaano-Akkadian" (cf. Izre'el 2005), seems to be Akkadian based on a old Babylonian dialect (cf. Rainey 1996:1732). But they were the work of autochthonous Syro-Palestinian scribes, whose mother tongue was not Akkadian but a northwest Semitic language which frequently seeped into the Akkadian language that they use, regarding morphology, syntax and lexicon. ${ }^{2}$ It is, therefore, an Akkadian language impregnated by elements from other linguistic systems, the local northwest Semitic languages and dialects, a morphosyntactic phenomenon which seems to go back to the letters from Taanak, in the middle of the 15th century B. C. (Rainey 1996:31-32). The proper character of this phenomenon of linguistic interference, of language mixing (spoken or arti-

${ }^{1}$ This article is the result of the Research Projects "Lenguas y dialectos en la Siria-Palestina del Bronce Final. Nuevas bases para el estudio del substrato semítico-noroccidental en la correspondencia de El-Amarna (s. XIV a. C.)" (BFF 2003-03883) and "Bancos de Datos Semíticos Noroccidentales: Desarrollo y aplicación de nuevas tecnologías para el estudio y conservación de da la documentación semítico-noroccidental del II y I milenio a. C.” (HUM 2007-65317), funded by the Spanish Ministerio de Educación y Ciencia within the National Plan for Scientific Research, Development and Technological Innovation $(\mathrm{I}+\mathrm{D}+\mathrm{I})$ and by the European Union (Feder Funds). This article gives some provisional results of our research on the scribes of the Cananean letters from El Amarna. The full results will be published in an adequately illustrated monograph. I wish to thank Dr. J. Marzahn (Vorderasiatisches Museum) and the Trustees of the British Museum for their kind permission to publish photographs of tablets keept in their museums which are used to illustrate this article.

${ }^{2}$ On the codeswitching phenomenon of the Canaanite glosses existing in the letters, see Izre'el 1995; Liverani 1998:24-27. 
ficial language, etc.), is still being debated, as shown, in particular, by the opinions and works of W. L. Moran (1992:xxii), ${ }^{3}$ A. Gianto (1990:10-11; 2000:131), ${ }^{4}$ A. F. Rainey (1996:32), ${ }^{5}$ Sh. Izre'el ${ }^{6}$ (1987, § 1.5) and E. von Dassow (2004). ${ }^{7}$ It is an essential aspect of the studies of Amarna which remains open to future investigations.

1.2. Throughout the last four decades there has been increasing evidence that the language used in the Amarna Palestinian letters is not uniform, which has led to focusing on the study of local corpora or subcorpora. ${ }^{8}$ But considerations such as those made by Sh. Izre'el (1991:9-10) seem to lean towards the need to further refining the criteria of linguistic research: "The diversity of the scholarly traditions attested in the dialectal continuum of the peripheral areas of Mesopotamia seems at times to be

${ }^{3}$ To W. L. Moran (1992:xxii), the language of the southern letters would be a pidgin which can only be described "as an entirely new code, only vaguely intelligible (if at all) to the West Semite because of the lexicon, and to the Babylonian because of the grammar."

${ }^{4}$ Gianto suggested that this language be labelled as an "interlanguage"; it could be the development of "a linguistic system in its own right ... a form of institutionalized interlanguage functioning as a contact language in a multilingual society" (Gianto 2000:131).

${ }^{5}$ Rainey agrees to this language being called an "interlanguage," but he also believes that it is impossible to define to what extent this language was actually spoken and that the syntax unquestionably reflects the (northwest Semitic) mother tongue of the scribes. Cf. also Rainey-Notley (2006:88): "Was it due to some dominant, creative personality in one of the scribal schools? Did this result in, or was it the result of, a spoken 'interlanguage' that developed among the local administrators?"

${ }^{6}$ For whom it is a "mixed language" which was actually spoken; cf. for example Izre'el (1987, § 1.5): "the formation of the Amarna jargon cannot be understood unless it were spoken in some way sometimes along its history ... a contemporary underlying spoken reality for the language attested in the Amarna letters can also be shown to have existed, even if not as a native tongue or in use in everyday speech."

${ }^{7}$ Von Dassow suggests that the language of the letters is in fact Canaanite written in an Akkadographic form: "the hybrid of Canaanite and Akkadian in which Canaanite scribes wrote was not a language of any kind, but an artifact of these scribes' use of cuneiform, and furthermore, that the language underlying their communication in cuneiform was not Akkadian but Canaanite" (von Dassow 2004:642); "Akkadographic writing of Canaanite ... Canaanite emerges as the spoken and written lingua franca of part of Egypt's empire in the Levant" (von Dassow 2004:674).

${ }^{8}$ See, for example, Smith 1998. 
very wide. Thus, the task of compiling one comprehensive homogeneous grammar of PA seems to be almost an impossible mission. A comprehensive collection of the common linguistic traits of this linguistic continuum has to be made after having described one by one its dialects and subdialects, namely the reduced, and sometimes very small and scanty, corpora of texts belonging essentially to the same or closely related genres, originated from the same area, and written by one or several scribes of a specific family or school within a limited span of time." On the other hand, the language of the various Canaanite letters is not uniform at all, as clearly explained by the same author: "The CanAkk [= Canaano-Akkadian] texts are characterized by inherent variation. Variation may be geographically dependent. It may depend on the scribal tradition of different cities, but also on imported traditions or variant local ones ... Geographic variation is dependent upon scribal traditions and scribal education. By and large, there is correlation between the provenance of a letter and its linguistic structure. The farther south one travels in Canaan the more remote becomes a CanAkk text from Akkadian, and the closer it becomes to the Canaanite vernacular of that region" (Izre'el 2005:3). Along this line of thought and observation, authors such as J. P. van der Westhuizen (1991; cf. § 10) and Sh. Izre'el (2003:72; cf. § 2.1) have highlighted very aptly the leading role that must be given to scribes in any linguistic approach to the Syro-Palestinian Amarna letters.

\section{Palaeographic identification of scribes}

2.1. In a recent article, Sh. Izre'el (2003:72) expounded a series of relevant observations regarding the need to take into account the "scribe factor" when studying the language of the Canaanite Amarna letters; for example: "the possibility that scribes who had received their education in one place did their service in a different location ... Scribes sometimes wrote letters for more than one Canaanite ruler," reaching the conclusion that "Since the Amarna letters themselves do not include any data on their respective scribes, the only way of revealing such discrepancies is by philological and linguistic analyses." In our opinion, though, it is also necessary to consider the palaeography of the scribes as an initial step to philological and linguistic analysis of the letters, although the three types of analysis must obviously be used in combination. Indeed, an interesting contribution to research into the different existing dialects in this epistolary corpus could be made by the palaeographic identification of the hands of the scribes and its further philological and historical exploita- 
tion, a methodology that has been successfully developed by disciplines related to Assyriology to a greater or lesser degree, such as Egyptology, ${ }^{9}$ Mycenology ${ }^{10}$ and, in a more distant field, studies on Mayan scribes. ${ }^{11}$ Within the study of late Bronze Syria-Palestine, J. Nougayrol (1955: XXXVI n. 2; 1968:1) announced the development of a similar work focused on the scribes from Ugarit which ultimately was not published ${ }^{12}$. Nevertheless, in this field, the recent work of W. H. van Soldt (2001b) on the scribe from Ugarit Nahiš-Šalmu can be seen. The identification of scribes of the Emar corpus produced the first conclusions in articles by J. Ikeda (1992; 1999), and the matter has been recently studied in depth by Y. Cohen (2009).

2.2. In the case of the Amarna Canaanite letters, the main criterion traditionally used in order to determine a linguistic corpus as an initial step to its philological and linguistic study has been the sender of the letters. However, in our opinion this criterion is insufficient and ought to be combined with the identification of the hands of the scribes who wrote the texts, as a preliminary basis for further philological and linguistic analysis of a given corpus, following in this sense the pioneering work of W. L. Moran (1975 = Huehnergard-Izre'el 2003:249-274) on the scribe of the letters of Jerusalem. The identification of the hands of the scribes must investigate, mainly, the general shape of signs, the overall ductus, the presence of telling or distinctive signs, the morphology of tablets as well as the distribution of the text on them (use of space, distance between signs, between lines). This line of research requires a combination of palaeographic, linguistic and historical criteria. The task, in this sense, is clearly facilitated by the numerous and precise observations made by $\mathrm{J}$. A. Knudtzon in his edition of the Amarna corpus on the scribes' writings, as well as on the colour and texture of the clay of the tablets. ${ }^{13}$

${ }^{9}$ More recently Egyptology has started to develop this aspect further, as shown by Janssen $(1987 ; 2000)$ as well as Donker van Heel and Haring (2003). I am indebted to Juan Carlos Moreno (CNRS-Lille) for these references.

${ }^{10}$ With the classic works by Olivier (1967), Palaima (1988), and the more recent work by Driessen (2000).

${ }^{11}$ Lacadena García-Gallo 2000.

${ }^{12}$ The work of Nougayrol was to be titled: Essai d'identification graphologique des tabellions d'Ugarit.

13 These are observations that Weber (1915) included in the appropriate places in his “Anmerkungen” to Knudtzon's edition. 


\section{Digital photography}

3.1. At present, epigraphic, palaeographic and philological work is enormously facilitated by the possibilities raised by digital photography and the Internet. ${ }^{14}$ As is well known, the Amarna corpus is widely dispersed between several museums around the world (Artzi 1985) and a substantial part of the texts are unpublished from a photographic point of view. On the other hand, the Vorderasiatisches Museum of Berlin letters are, along with the small group from the Louvre Museum, the only letters which have good quality copies, carried out by O. Schroeder (1914) and F. Thureau-Dangin (1922) respectively. Photographing the Amarna tablets has made, therefore, an essential contribution to our research.

3.2. To date, we have been able to photograph the Canaanite letters kept at the Vorderasiastisches Museum (Berlin), the British Museum (London) and the Louvre (Paris). These photographs allow us to observe the actual physical aspect of the texts, to establish palaeographic comparisons between texts kept at different museums, to illustrate publications with group and detailed photographs that allow the reader to have a graphic complement as an independent item to verify our analyses and conclusions, as well as to seek a digital reunification of this artificially dispersed documentary corpus in the future as an initial step to a desirable comprehensive publication on the Internet. To date, in co-operation with Joachim Marzahn (VAM, Berlin), we have been able to publish on the Internet the Canaanite letters kept at the Vorderasiastisches Museum. ${ }^{15}$ The West Semitic Research Project, and academic project affiliated to the University of Southern California School of Religion and directed by Dr. Bruce Zuckerman, also provides, through the database "InscriptiFact," high quality photographs corresponding to over one hundred Amarna letters housed at the Vorderasiatisches Museum of Berlin and at the British Museum. ${ }^{16}$

\section{Petrography}

4.1. The recent publication of the analysis and results of the petrographic project carried out by Y. Goren, I. Finkelstein and N. Na'aman (2004) on

14 The "Cuneiform Digital Library Initiative," of the University of California (Los Angeles) and the Max Planck Institut (Germany), is good instance in this sense: http://cdli.ucla.edu.

${ }^{15}$ http://amarna.ieiop.csic.es.

${ }^{16}$ http://www.inscriptifact.com. 
a substantial part of the Amarna letters has contributed greatly to the Amarna studies. ${ }^{17}$ It is essential work in order to gain more or less accurate knowledge of the physical origin of the tablets, which also provides new elements for research and reflection on the political relations between the various Canaanite kingdoms amongst themselves, between them and the Egyptian administration, on the training and administrative role of scribes, as well as on the study of the various Canaanite linguistic corpora.

4.2. Palaeographic and philological studies must take into consideration the results of petrographic analysis since, in our opinion, both types of approach to the documents complement each other, and to a greater degree, lead in the same direction. The following example may illustrate this. Through palaeographic, orthographic, grammar and content criteria we suggested the adscription of the unheaded letter EA 308 (it does not include any toponyms or anthroponyms) to the corpus of the town of Ashkelon (Vita 2000a); on the other hand, and separately, Y. Goren, I. Finkelstein and N. Na'aman (2004:311) conclude that this tablet must come from Gaza or Ashkelon. As these authors point out, J. A. Knudtzon had already placed this letter near the letters of Ashkelon. The origin of letter EA 308 may, therefore, be placed with high certainty in this town.

\section{Correction factors}

5.1. Once the hands of the scribes are identified and the petrographic data is incorporated into the analysis, a series of correcting factors will have to be considered in order to refine, through philological and historical criteria, the resulting data. For example, if a letter was dictated by King A not to his scribe but to the scribe of King B; in that case, the dialect of that letter may reflect that of the town of King A and not, as could be expected, that of King B. Such is, for instance, the case, yet to be investigated in this sense, of letters EA 136-138 of Rib-Adda, King of Byblos, drafted during his exile in Beirut (cf. also Izre'el 2003:72). These three letters are commonly seen as part of the dialect of Byblos (cf. Gianto 1990:5). However, as pointed out by J. A. Knudtzon (1907-1915:1236), the palaeography of these letters does not match that of the scribes of Byblos, but fully that of the scribe of the King of Beirut. In principle, there-

${ }^{17}$ The publication of this work was preceded by a series of articles on this subject; see Goren 2000; Goren-Finkelstein-Na'aman 2002; 2003a; 2003 b. 
fore, letters EA 136-138 could also be examples of the language of Beirut. It is also possible, at least in theory, that Rib-Adda dictated the letters and the scribe from Beirut copied the message literally, in which case these letters would be part of the dialect of Byblos. But there is yet a third option: that the scribe blended in the message both his own linguistic elements and those from the King of Byblos, thus producing a mixed dialect. It is a question of trying to resolve philological and linguistic problems that may arise once an initial draft of the dialectal map of SyriaPalestine has been made, and it will be necessary to differentiate for each site between the historical and the linguistic corpus (see also § 10).

\section{Epistolar corpus of the Kings of Gezer}

6.1. Everything that has been explained so far can be exemplified through the analysis of a given case: the scribes of the Kings of Gezer. ${ }^{18}$ It consists of resuming our previous work on the subject (Vita 2000b), updating it through the progress made by our own research, incorporating the petrographic results of Y. Goren, I. Finkelstein and N. Na'aman (2004) and illustrating the material and palaeographic observations with a number of digital photographs. It must be noted that J. A. Knudtzon's comments are always our principal starting point and guide.

6.2. The Amarna archive contains preserved letters from three Kings of Gezer ${ }^{19}$ who, chronologically, are Milki-Ilu, Baslu-šipți ( ${ }^{\mathrm{d}}$ IŠKUR.DI.KUD) ${ }^{20}$ and Yapahu. The first is the sender of five letters (EA 267-271), the second is the sender of three (EA 272, 292-293) and the third sends five letters (EA 297-300, 378). A. F. Rainey (2003:201-202; cf. also Vita 2006: 440-441) could recently pinpoint Baslu-šipți as the sender also of letter EA 272. ${ }^{21}$ Before, J. A. Knudtzon had repeatedly pointed out the close material and palaeographic relationship that he had noted between this

\footnotetext{
${ }^{18}$ EA Gazru, OT Gezer; cf. Belmonte 2001:79.

${ }^{19}$ On the possibility of a fourth King of Gezer as the author of EA 294, see later sub $\S 8.7$.

${ }^{20}$ On the possible interpretation of this name see Hess 1993:53, Liverani 1998:453-454 s. v. "Addu-dani/Ba'lu-shipti" and van Soldt 2001b:587; 2002: 73: Bålu/dān(u).

${ }^{21}$ According to the collation by Rainey (2003:201-202), the first four lines of

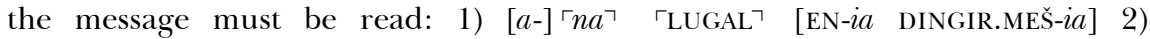

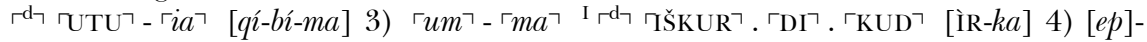
$\ulcorner r i\urcorner\ulcorner\check{s} a\urcorner^{?}\left\ulcorner_{\mathrm{GIIR}}\right\urcorner .\ulcorner\mathrm{MEŠ}\urcorner-[k a]$.
} 
letter and the letters of Milki-Ilu. ${ }^{22}$ The precise identification of the scribe of EA 272 is considered later on in section $\S 7.2$. In total thirteen letters from Gezer kings are preserved.

6.3. This group of texts (obviously without including EA 272) has been the subject of various, important linguistic studies by Sh. Izre'el (1978), J. L. Hayes (1984:55-123) and J. P. van der Westhuizen (1995). From the historical point of view, this corpus is completed by letter 369 (cf. also $\S 7.4$ ), from the Pharaoh to Milki-Ilu. ${ }^{23}$

\section{Scribes of the correspondence of the Kings of Gezer}

As we will now try to demonstrate, the thirteen letters of the Kings of Gezer may have been written by a total of only two, perhaps three, scribes.

\subsection{Scribes of Milki-Ilu's letters}

The five letters from Milki-Ilu (EA 267-271) seem to have been written by the same scribe. The palaeographic unity of these letters has already been highlighted by J. A. Knudtzon when glossing the letters EA 272-280; ${ }^{24}$ plates 1-2 confirm the accuracy of his observations. The petrographic analysis carried out by Y. Goren, I. Finkelstein and N. Na'aman (2004:

22 "[EA 272] Nach Schrift und Ton den Milkilu-Briefen (267-271) gleich" (Knudtzon 1907-1915:1328, Anm. 1); “Die Absenderin von No. 273 und 274 steht nach dem Inhalt ihrer Briefe ... höchstwahrscheinlich in irgendwelcher Verbindung mit Milkilu, wofür auch spricht, daß ihre Briefe nach Schrift und Ton denen Milkilus (267-271) gleich sind. Dies gilt allerdings auch von 272 und 275280" (Knudtzon 1907-1915:1328, Anm. 2; our use of italics); "Die Tafeln No. 275277 sind nach Schrift und Ton einander und Nr. 267-274 ebenso wie 278-280 gleich" (Knudtzon 1907-1915:1329, Anm. 1). See also Goren-Finkelstein-Na'aman (2004:275): "Our investigation confirms Knudtzon's hypothesis and indeed suggests that EA 272 was made at Gezer."

${ }^{23}$ Gezer has also provided a fragment of an envelop of a letter from the old Babylonian period, a fragment of letter possibly from the Amarna period (cf. on this subject also Albright 1943:30), two legal documents from the Neo-Assyrian period and a tablet with possible drawings of an astronomical nature (HorowitzOshima-Sanders 2002:756; 2006:51-60; Horowitz-Oshima 2004:37).

${ }^{24}$ Knudtzon 1907-1915:1328, n. 2: "Die Absenderin von Nr. 273 und 274 steht nach dem Inhalt ihrer Briefe (vgl. bes. 273, 23f.) höchstwahrscheinlich in irgendwelcher Verbindung mit Milkilu, wofür auch spricht, daß ihre Briefe nach Schrift und Ton denen Milkilus (267-271) gleich sind. Dies gilt allerdings auch von 272 und 275-280 (Knudtzon 1907-1915:1328, n. 1: 'Nach Schrift und Ton den Milkilu-Briefen (267-271) gleich')" (our use of itallics). 
271-272) ${ }^{25}$ on this group of tablets demonstrates that Gezer is the most probable place of preparation and dispatch of these letters.

\subsection{Scribes of Ba'lu-šiptị's letters}

J. A. Knudtzon pointed out the close palaeographic relationship between letters EA 292 to 294, as well as between these and Milki-Ilu's letters (§ 7.1). However, he indicates the existence of slight palaeographic variations between both groups, in particular in signs $\mathrm{IL}_{5}$, EN and GÌR. ${ }^{26}$ Plate 3 shows the palaeographic proximity between letter 271, from Milki-Ilu, 292 and 294, but also some differences in the general ductus. ${ }^{27}$ As shown by plate 4 , the sign Gìr has, indeed, slight variations but there are also significant differences in the writing of MEŠ and AM. These differences, on the one hand, highlight the internal palaeographic unity of 292 and 294 (cf. also sign $\mathrm{IL}_{5}$ on plate 4 ) and, on the other hand, make them different from Milki-Ilu's letters. However, as shown also by plate 4, there are not any significant differences in the rest of the signs of both groups of letters, as for example the writing of syntagm LUGAL EN-ia, which include signs LUGAL, EN and IA, which are relevant from a palaeographic point of view. As shown also by plates 3 and 4, letter 272 follows the same line as the rest of Ba'lu-šipti's letters. The petrographic analysis shows that letters 272 and 292 were, very probably, sent from Gezer (cf. Goren-Finkelstein-Na'aman 2004:273 and 275). On the author and origin of EA 294, see below sub $\S 8.7$.

\subsection{Scribes of Yapahu's letters}

A different scribe from the one who wrote Milki-Ilu's letters must have been the author of four of the letters of Yapahu. The palaeographic unity of the three letters EA $298-300$ was already noted by J. A. Knudtzon. ${ }^{28}$ As

${ }^{25}$ Except for EA 267, currently in the Cairo Museum.

26 "Die Tafeln 292-294 scheinen ganz dieselbe Schrift zu haben ... Die Schrift findet sich auch auf 296 und 297, und ist derjenigen der Milkilu-Tafeln usw. ähnlich, nicht aber in allen Einzelheiten gleich (so wiechen el, en und šêpu etwas ab). Inhaltlich gehören 292 und 294 zusammen" (Knudtzon 1907-1915:1344, n. 2); "Die Tafel [EA 296] stimmt in bezug auf Schrift mit 292-294 und in bezug auf Ton mit 294 überein” (Knudtzon 1907-1915:1346, n. 1); “Nr. 297 ... weist dieselbe Schrift auf wie 292-294 und 296” (Knudtzon 1907-1915:1346, n. 2).

${ }^{27}$ Letter EA 293 is in Cairo. On the identity of the sender and the palaeography of EA 294 see later on sub $\S 8.7$.

${ }^{28}$ Knudtzon 1907-1915:1346, n. 2: "298-300 gleichen einander sowohl in Schrift als in Ton." 
also shown by A. Millard (1965:143), EA 378 could have been the work of the same scribe, by whom four letters would therefore be preserved (cf. also Vita 2000b:76). Plates 5-6 show the palaeographic unity of EA 298300 and 378. The petrographic research of Y. Goren, I. Finkelstein and N. Na'aman (2004:273-275), concludes that the four letters were not sent from Gezer but from Gaza.

The position of the scribe of letter EA 297 remains to be elucidated. As we have seen (cf. n. 26), J. A. Knudtzon includes this letter, from the palaeographic point of view, amongst the group of letters of Ba'lu-šipti (EA 292-294). Like EA 292 and 294 (§ 7.2), plate 4 shows that EA 297 is also different from the letters of Milki-Ilu in signs GìR, MEŠ and AM, but not in LUGAL EN-ia. Palaeographic data indicate that the scribe of EA 297 is undoubtedly a different scribe from that of letters EA 298-300 and 378; it is in fact the same scribe who wrote EA 292 and 294 (cf. plate 7). The petrographic study establishes that it was sent from Gezer (GorenFinkelstein-Na'aman 2004:273).

\subsection{The scribe of letter EA 369}

W. L. Moran (1992:366, n. 1) pointed out a series of items of ductus, grammar and content that could differentiate letter EA 369 from the rest of letters dispatched from the Egyptian chancery. Later, Sh. Izre'el (1995: 109-118) provided elements that were to show that this letter could have been written by a scribe from Gezer; EA 369 could thus be the work of a third scribe from Gezer who, at least in this case, may have written the letter from Egypt. However, as E. von Dassow points out (2004:655, n. 33), the question of whether this scribe had an Egyptian or Canaanite origin may not be considered settled yet.

\section{Scribes of Gezer and correspondence of kings from other localities}

8.1. As shown here, the scribe who wrote Milki-Ilu's letters seems to have written also some letters for kings from other places, namely Lapuma, Gath and Gintu-Kirmil, perhaps also Beth-shemesh. It is also possible that he may have been the author of a letter sent from Ashdod or Jaffa.

8.2. As we have seen above (cf. n. 22), J. A. Knudtzon pointed out the palaeographic similarity between letters 273 and 274 and between these and Milki-Ilu's letters. In his comment he adds: "Die Form der Tafel 273 ist ganz wie die von 271, doch die Grösse etwas verschieden" (Knudtzon 1907-1915:1328, n. 2). Plates 8 and 9 illustrate this fact. The sender of 
both letters is NIN-UR.MAH.MEŠ, Queen of Șapuma. ${ }^{29}$ At the time of drafting the letters she must have been in exile in Gezer: in EA 274 she informs the pharaoh that her town has been taken by the sapiru (Vita 2000b:72). The petrographic analysis of EA $273^{30}$ confirms that the tablet was produced in Gezer (Goren-Finkelstein-Na'aman 2004:276-277).

8.3. The three letters EA 278-280 were sent by Šuwardata, probably the King of Gath (Gimtu; cf. Liverani 1998:80; Goren-Finkelstein-Na'aman 2004:279). J. A. Knudtzon (1907-1915:1329, n. 2) says: "Die Briefe des Šuwardata zerfallen ... nach ihrer Schrift in zwei Klassen: a) Nr. 278-280, welche dieselbe Schrift haben wie die Milkilu-Tafeln und andere oben erwähnte, die mit diesen übereinstimmen; b) Nr. 281-284, die einen anderen Schrifttypus aufweisen." Letters EA 278-280 also seem to have been written by the scribe of Milki-Ilu, as shown by plate 10 . The historical reason for this could be the close political relationship existing between Milki-Ilu and Šuwardata: letter EA 278 documents the good relations between both rulers; two other letters, EA 271 (from Milki-Ilu) and 290 (from `Abdi-Heba of Jerusalem), show that they were both united at some stage. From the petrographic point of view, letter 279 seems to have been sent from Gath (Goren-Finkelstein-Na'aman 2004:280-281 ${ }^{31}$ ). Regarding EA 278, also linked to the group of letters EA 275-277, see below sub § 8.4.

8.4. Letters EA 275 and 276 are sent by Yahzib-Adda, King of an unknown locality; EA 277 lost both the name and locality of the sender ${ }^{32}$ This group is rounded off with EA 278 from Šuwardata (cf. § 8.3). All four of them make up a homogeneous group of letters, both regarding their contents and their palaeography: they produce an identical message and, as shown by plate 11, were written by the same scribe who wrote the letters of Milki-Ilu (Vita 2000b: 73). From the petrographic point of view, all four letters seem to have a common origin (Goren-Finkelstein-Na'aman 2004:291). N. Na'aman and Y. Goren (in Goren-Finkelstein-Na'aman 2004:291) suggest that they could have been sent at the same time from the capital of Yahzib-Adda, very likely situated near Gath and Gezer, perhaps Beth-shemesh. Should this be the case,

${ }^{29}$ Liverani (1998:123), for whom "lo stile sobrio dell'indirizzo e dei saluti non sembrano meridionali," places letters EA 273 and 274 in the Middle Jordan. See, however, Vita 2005 on the possible placing of Șapuma near Gezer.

${ }^{30}$ Letter EA 274 is in Cairo.

${ }^{31}$ EA 280 is in Cairo.

${ }^{32}$ Liverani (1998:111) includes EA 277 within this corpus "perché del tutto analoga alle due precedenti." 
and if the author of these letters is the scribe of Gezer, he must have travelled to this town. As an alternative, they point out the possibility that they were sent from Gezer, but this would mean "that the Gezer scribe chose a specific mixture for these four letters which was not used for the other Gezer tablets" (Goren-Finkelstein-Na'aman 2004:291).

8.5. Tagi is the sender of EA 266. It is highly probable that his capital was Gintu-Kirmil, a locality which could be the modern Jatt (cf. Goren-Finkelstein-Na'aman 2004:257). Three letters from this King are preserved (EA 264, 265 and 266) which, according to the petrographic analysis of the tablets, come from Gintu-Kirmil (Goren-Finkelstein-Na'aman 2004:257). J. A. Knudtzon had already noted that the writing of EA 266 differs from the other two, although without making a link with any other known scribe. ${ }^{33}$ Actually, it is a letter written by the scribe of Milki-Ilu (cf. Vita 2000b:71-72 and plate 12). Other Amarna letters ratify the close relationship between Milki-Ilu and Tagi: the latter is Milki-Ilu's father-in-law (EA 249) and they are both political and military allies (EA 289). The other two letters (EA 264 and 265) are the work of another scribe.

8.6. The sender of letter EA 296 is Yahtiru, Canaanite in name but brought up in Egypt and still integrated within the Egyptian administrative structure (Liverani 1998:65). In his message, as M. Liverani (1998:65) outlines: "Dichiara di proteggere le porte urbiche di Gaza e Giaffa, città abbastanza distanti tra loro e separate dal regno di Ascalona: dunque aveva a carico il collegamento viario più che le località in questione. Ł̀ una funzione atipica, che produce una lettera atipica." J. A. Knudtzon pointed out in various comments the palaeographic relationship between EA 296 and other letters from Gezer, in particular the close palaeographic relationship with EA 292294 (§ 7.2) and 297 (§ 7.3). ${ }^{34}$ According to J. A. Knudtzon, therefore, from the palaeographic point of view, letters EA 292-294 and 296-297 are part of a group; see also below sub $\S 9$. Thus, the letter might have been written in Gezer itself. M. Liverani (1998:65) attributes it to the towns of Hazzātu (capital of the Egyptian province of Canaan; cf. for example Katzenstein 1982) and Jaffa. H. J. Katzenstein (1986) on the contrary, suggested that Yahtiru be seen as a ruler of the town of Muhhazu, near Gezer. Based on

33 “... weil die Tafel [EA 266] nicht dieselbe Schrift aufweist wie die zwei vorhergehenden" (Knudtzon 1907-1915:1329, n. 2); "da EA 266 sowohl nach Schrift (vgl. z. B. En) als Ton von den zwei andern abweicht" (Knudtzon 1907-1915:1323, n. 2).

${ }^{34}$ Cf. above n. 26 and Vita 2000b:74. 
the petrographic analysis of the tablet, Y. Goren, I. Finkelstein and N. Na'aman (2004:293) suggest that it may have been sent from Ashdod or, as a plausible alternative, from Jaffa.

8.7. W. L. Moran (1992:336) attributes letter EA 294 to Ba'lu-šipți (which he reads "Adda-danu"); in the same manner, although with some doubts, M. Liverani (1998:104 and n. 158). The problem lies in the uncertain reading of the anthroponym. Sh. Izre'el (1978:15), after collation of the tablet, suggested the name of the sender be read as ȘI-x-X-NI. Y. Goren, I. Finkelstein and N. Na'aman (2004:293 $)^{35}$ also think that EA 294 could not have Ba'lu-šipți as the sender and that the name of line 3 ought to be read ȘI-X-X-NI; they also specify that "the first sign is clearly și and the last is $n i$... Hence, the author of EA 294 is most probably not the author of EA 292" (Goren-Finkelstein-Na'aman 2004:293, n. 3; as already concluded by Izre'el 1978:15, n. 16). Previously, N. Na'aman (1997:615) had suggested the reading SI-X-IB ${ }^{3}$-NI. The line is in a poor state of preservation and would require a new collation. Should the reading of the first and last sign be confirmed, it would indeed be a different sender from Bålu-šipți. As pointed out by M. Liverani (1998:104, n. 158), proximity in style and content of letter EA 294 and the letters from Gezer may indicate that the sender was a new King of Gezer, or failing that, the King of a neighbouring locality. Available palaeographic data, as seen above sub $\S 7.2$, do not allow us in any case to discount that the scribe of EA 294 may have been the same as the scribe of EA 272 and 292. The petrographic analysis of the tablet indicates that it could have been sent from Ashdod (Goren-Finkelstein-Na'aman 2004:293-294).

\section{The Gezer letters: historical corpus, linguistic corpus and scribes' mobility}

9.1. The aforementioned elements sub $\S \S 7-8$ allow us to conclude, provisionally, that the thirteen letters from Kings of Gezer were written by three, perhaps two scribes. Milki-Ilu might have used only one scribe, Ba'lu-šipți may have also used only one scribe, perhaps a different one from the scribe who wrote Milki-Ilu's letters, and Yapahu might have used two scribes: EA 297 would be the work of the scribe of Ba'lu-šipti, the rest of his letters would have been written by another scribe. Hence, at least Bålu-šipți and Yapahu would have shared a same scribe. The

${ }^{35}$ Without mentioning the collation by Izre'el. 
three Kings seem to have sent letters from Gezer, but some of them would have also been sent from outside the capital of the kingdom, from Ashdod (Ba'lu-šipți) and Gaza (Yapahu).

Two of these scribes from Gezer could have also written letters for kings of other places. The scribe of Milki-Ilu would be the author of the two letters of Queen NIN-UR.MAH.MEŠ of Sapuma, of at least two letters of Šuwardata, King of Gath, of two letters of Yahzib-Adda (unknown locality) and of one letter of Tagi, King of Gintu-Kirmil. These letters would have been sent from Gezer, Gath and, perhaps, Beth-Shemesh. On the other hand, the scribe of Baslu-šipți would have written a letter for Yahtiru (Gaza, Jaffa?), probably sent from Ashdod or, perhaps, Jaffa.

9.2. The elements described above sub $\S 7.2$ show that the script used by the scribe of Milki-Ilu and the script used by the scribe of Baslu-šipti are very similar and are, in general, identical, although there are significant variations in the writing of some signs. The petrographic analysis of this group of tablets also shows that the geographic origin of the tablets is different. However, on the basis of considerations of chronology, contents and palaeographic nature, it is questionable whether the scribe of Baslušipți's letters, of a letter from Yapahu (EA 297) and of the Yahtiru letter (EA 296) was not in fact the same scribe who wrote Milki-Ilu's letters.

The chronology of the texts allows us, indeed, to consider the possibility that all the letters were written by the same scribe, who may have been at the service of, at least, three Kings of Gezer (cf. also Vita 2000b:75). The four letters EA 292-294 (Ba'lu-šipți) and EA 297 (Yapahu), from Kings of Gezer, are chronologically placed in the middle of the reign of Amenophis IV (Campbell 1964:126, 135). EA 296 (Yahtiru) may be dated to an earlier period, the final part of the reign of Amenophis III and early Amenophis IV (Campbell 1964:100, 134), like the letters of the scribe of Milki-Ilu EA 266-280 (Campbell 1964:134). From a biological point of view, thus, it is possible that all the letters were written by one scribe. In this case, the script variations which are noticeable between letters written far apart in time could be explained as a personal evolution of the scribe's writing style.

An additional argument in favour of the unity of the hand that wrote this group of texts is offered by letters EA 266 (Tagi), 292 (Ba'lu-šipṭi) and 296 (Yahtiru). ${ }^{36}$ The three letters have a long poetical introduction, almost identical in detail in all three (cf. Katzenstein 1986:7; Moran

${ }^{36}$ Cf. van der Toorn 2000:107, n. 99: "EA 266 ... 292 ... 296 ... (all three from Gezer)." 
1992:335; Vita 2000b:74). In our opinion, the best possible explanation for this is that the three of them were written by the same scribe, who may have used the same introduction on three different occasions in his life for letters from three different rulers.

9.3. Taking into account all the above-mentioned considerations sub $\S 9.2$, we suggest the following allocation of documents to the historical and linguistic corpus of Gezer, as well as to the identified scribes.

- Historical corpus: EA 267-272, 292-293, 297-300, 369, 378. Total: 14 letters.

- Linguistic corpus: EA 266-280, 292-294, 296-300, (369; cf. § 7.4), 378. Total: 24 (25) letters.

- Scribes:

- Scribe 1. EA 266-280, 292-294, 296, 297. Total: 20 letters.

- Scribe 2. EA 298-300, 378. Total: 4 letters.

(- Scribe 3. EA 369; cf. § 7.4).

\section{Final considerations}

10.1. As we already pointed out in previous works (Vita 2000b:76, cf. above $\S 6.1 ; 2002: 35)$, the identification of the hands of the scribe results in the re-organization of the linguistic corpora of a significant number of Canaanite localities. These adjustments can be divided into three types: increase in number of texts assignable to the dialect of one locality, decrease in the number of texts assignable to the dialect of another, and the complete disappearance of texts which, in principle, may have attested to the dialect of a particular locality. In the case of Gezer, the number of texts which are available for the linguistic analysis of their dialect varies, with a very high degree of certainty, from 13 to, at least, 24 texts (§9.3). Within this group of documents that attest to the dialect of Gezer, there are letters sent by kings from, at least, three other localities (Șapuma, Gath and Gintu-Kirmil), a figure which might even reach as many as five separate locations (with the possible addition of Beth-shemesh and Ashdod or Jaffa, cf. above $\S 8$ ). Consequently, the number of texts of some linguistic corpora, such as those from Gath or Gintu-Kirmil, is reduced, and villages such as Șapuma are left with no text at all to document their dialect. The main palaeographic relationships identified so far between 
the localities could also be the basis for a future dialectal map of the Canaanite dialects of Amarna. ${ }^{37}$

10.2. The scribe thus becomes a key element for the linguistic study of the Canaanite dialects of the Amarna age. As we have already explained (cf. $\S 1.2$ ), the importance of scribes in this sense was already pointed out by other authors. ${ }^{38}$ In this context, as we have tried to show here, we believe that we can accept as a working hypothesis that a scribe reproduced in his writings his own language and grammar first and foremost, even more so than the language of the location where he worked (remember the existence, well proven in Canaan, of foreign scribes). In this sense, we would like to restate our opinion that it is desirable to start from the identification, initially palaeographical, of the scribes who wrote the letters, as the main criterion for a preliminary linguistic demarcation of the Canaanite dialects of Amarna (cf. also § 2.1). The letters from kings of different kingdoms that were written by the same scribe, must, in principle, be considered as a unit from the point of view of the language.

10.3. As previously pointed out, the palaeographic and petrographic results must be subject to a series of correcting factors. To the aforementioned factors (cf. §5), the variables of chronology and geographic origin of the letters will also have to be considered. Apart from the mention of well identified anthroponyms in the letters, as well as toponyms of well-known locations or identified through historical geography studies, the petrographic analysis of the Amarna tablets $(\S 4)$ has contributed to enriching the range of origins (either certain or likely) of the various letters. As a result, the equation "kings-scribes-places of draft and dispatch of the letters" has become notably more complicated; this issue will have to be looked into specifically in future in order to be understood and resolved. In the case of Gezer, as we have seen (cf. $\S 8$ ), most of the letters sent by its kings come from Gezer itself but some of King Yapahu's letters were

${ }^{37}$ In the process of palaeographic identification of the scribes, the fact that a scribe might have changed his orthography over the years will have to be taken into consideration (as is the case of the scribe of letters EA 221-223, see Vita 2002; cf. also §9.2).

${ }^{38}$ Mainly in the works of A. F. Rainey, Sh. Izre'el, J. P. van der Westhuizen, K. van der Toorn and, more recently, E. von Dassow. See, particularly, the consideration of J. P. van der Westhuizen 1991:54-55, 79-80; 2000:447. 
sent from Gaza $(\S 7.3),{ }^{39}$ where he had used his own scribe to write his letters to the pharaoh. ${ }^{40}$

In the case of the letters written by the scribe of Gezer for other kings, Y. Goren, I. Finkelstein and N. Na'aman (2004:279) suggest that the scribe of Gezer could have travelled to those allied kingdoms to write the letters. Based on this explanation is the idea that there may have existed the figure of an itinerant scribe (cf. Goren-Finkelstein-Na'aman 2004: 129) and that some kings may have lacked scribes (cf. Goren-FinkelsteinNa'aman 2004:133, 225). However, it seems hard to imagine the possibility of the existence of a kingdom with no scribes (that is, of an administration and a chancery without their own scribes) and, on the other hand, it is also possible that the allied kings of Gezer may have travelled to this locality and used the local scribe to write their correspondence. A clear example in this sense would be the case of the Queen of Sapuma, since at the time of writing and dispatching the two letters that are preserved from her (EA 273 and 274) she must have been in exile in Gezer (cf.

${ }^{39}$ Y. Goren, I. Finkelstein and N. Na'aman (2004:323-324) provide the following possible historical explanation regarding this: "Yapahu, the ruler of Gezer, was in deep trouble ever since he ascended the throne. In trying to consolidate his position, he begged repeatedly for Egyptian military aid. Since four of his letters were dispatched from Gaza, he must have travelled there several times, imploring the local authorities for help and writing desperate letters to the Pharaoh."

${ }^{40}$ A similar case is provided by the letters of Zitriyara (EA 211-213), King of an unknown locality, whose writing and content seem to point towards an area in the north of Canaan (Goren-Finkelstein-Na'aman 2004:307). Liverani (1998a: 254) allocates these letters, with reservations, to southern Syria, because they contain also a certain formula which could indicate a southern Palestine origin. However, the petrographic analysis of the tablets could indicate that the three letters may have been sent from Gaza (Goren-Finkelstein-Na'aman 2004:307: "the only possible interpretation of their southern provenance is that he [= Zitriyara] appeared before the Egyptian officials in the administrative centre at Gaza and wrote his letters from there"). In this case, the three letters are clearly the work of three different scribes; some of the three scribes may have been Zitriyara's own scribe, but perhaps the variety of scribes for such a small corpus may be better explained as being the work of various scribes of the Egyptian administration of Gaza. Y. Goren, I. Finkelstein and N. Na'aman (2004:323) have identified up to 22 letters from eight different kings, whose kingdoms range from Beirut to Lachish, which may have been dispatched from Gaza. As opposed to the case of Yapahu of Gezer, the historical circumstances which may account for each particular instance are yet to be discovered (see on this subject the considerations by Goren-Finkelstein-Na'aman 2004:324). 
$\S 8.2$ ); the Amarna letters also provide other cases of this kind (cf. GorenFinkelstein-Na'aman 2004:132).

10.4. To date, our work has dealt with approximately 275 Canaanite letters, from which about 95 scribes have been identified. It is foreseeable that this figure may change towards the end of our research, but probably, not significantly. These scribes (their writing, their language, their education and their possible belonging to a certain school, their indigenous or foreign nature) will have to be studied bearing in mind that the work of some may be very well represented whereas for others we may have only one or two letters. 
EA 268

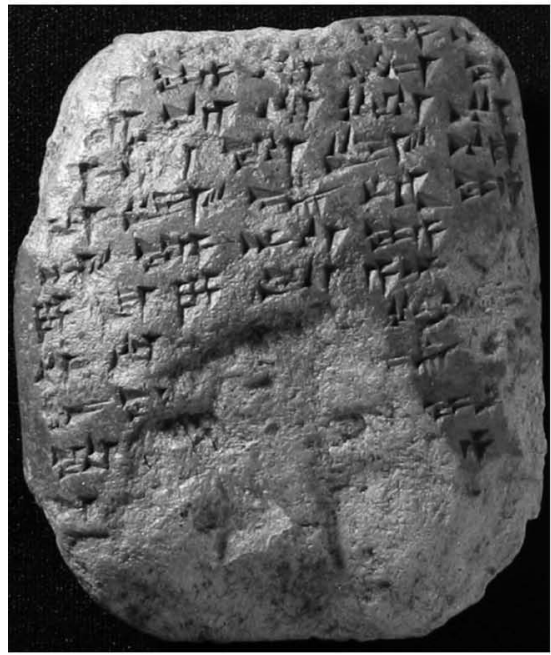

EA 270

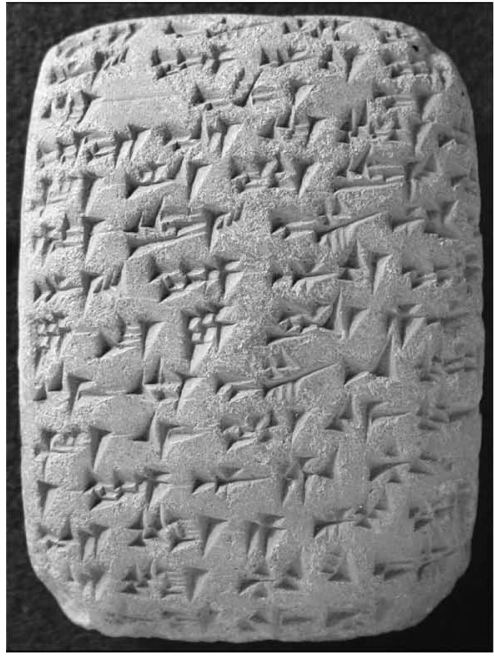

\section{EA 269}

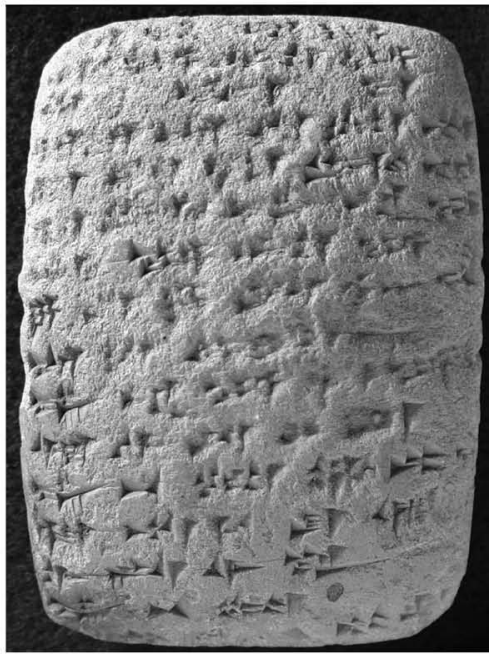

EA 271

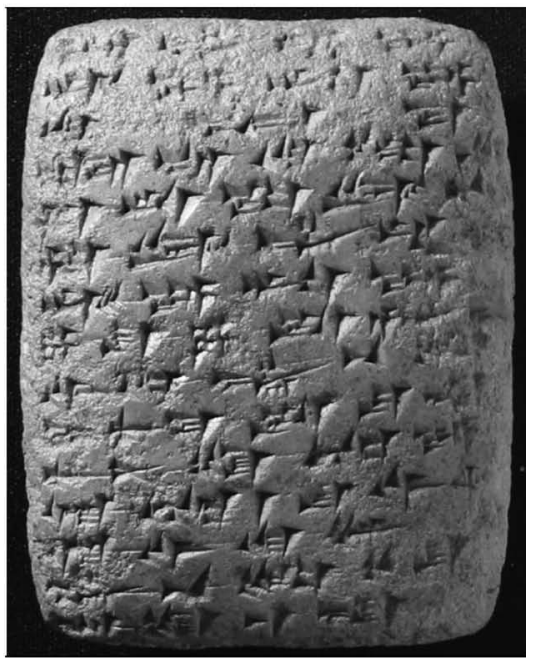

Plate 1 


\begin{tabular}{|c|c|c|c|c|c|}
\hline & gìr.meš & & IA & $\mathrm{BE}$ & LI \\
\hline EA 268 & ping & EA 270 & serf (7) & $24(9)$ & $2 y-1)$ (25) \\
\hline EA 270 & Her & EA 271 & sytp (7) & & LAf \\
\hline EA 271 & 150 (6) & EA 269 & bin (7) & $>$ (12) & $4+2=9$ \\
\hline EA 269 & $\left.4 x^{2}\right)_{(5)}$ & EA 268 & seris: (6) & & Iter| (3) \\
\hline
\end{tabular}

\begin{tabular}{|c|c|}
\hline & 7-šu 7-ta-a-an \\
\hline EA 268 & 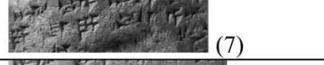 \\
\hline EA 270 & 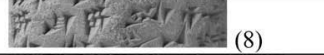 \\
\hline EA 271 & 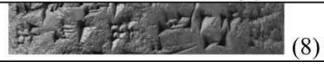 \\
\hline
\end{tabular}

Plate 2 
EA 292

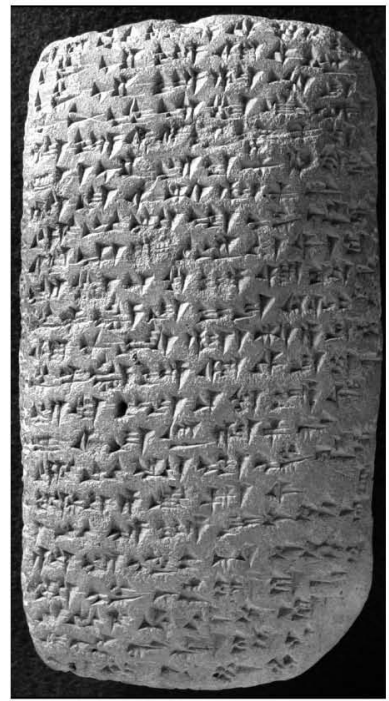

EA 294

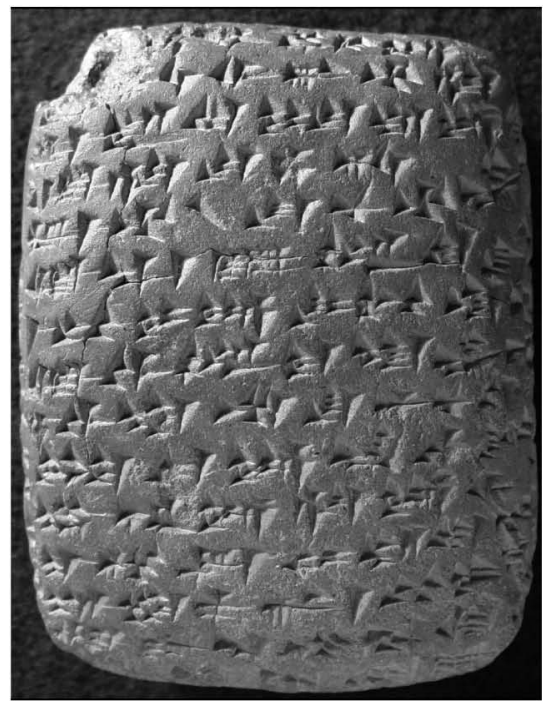

EA 272

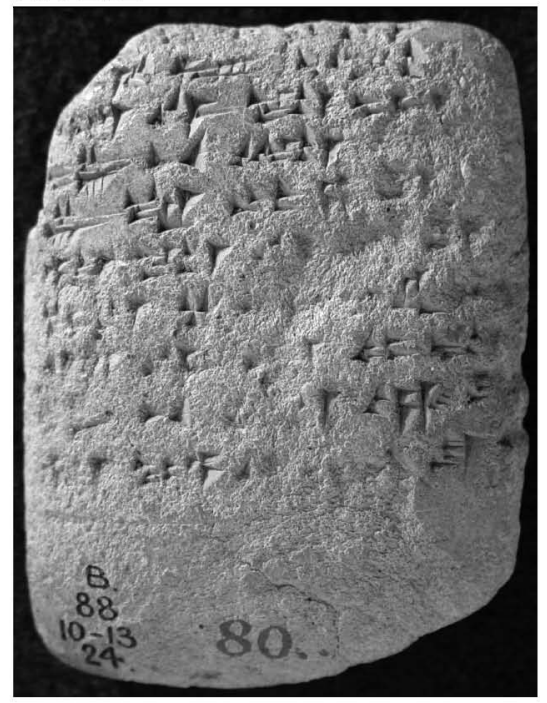

EA 271

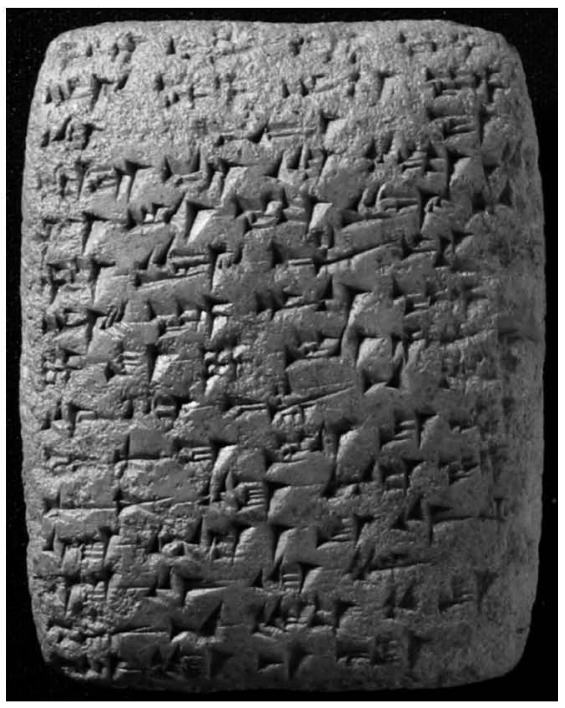

Plate 3 


\begin{tabular}{|c|c|c|}
\hline & gìr.meš & meš \\
\hline EA 271 & मfनl (6) & Fil (7) \\
\hline EA 292 & $y^{2}+12$ & If \\
\hline EA 296 & ferts (6) & 8. (5) \\
\hline EA 297 & $p^{2}=12$ & if (6) \\
\hline EA 272 & & 24) \\
\hline EA 294 & & $f^{-1}$ \\
\hline
\end{tabular}

\begin{tabular}{|l|r|}
\hline & \multicolumn{2}{|c|}{ am } \\
\hline EA 270 & (23) \\
\hline EA 272 & (11) \\
\hline EA 292 & (7) \\
\hline EA 294 & (6) \\
\hline EA 296 & (13) \\
\hline EA 297 & (7) \\
\hline
\end{tabular}

\begin{tabular}{|c|c|c|}
\hline & lugal en-ia & $\mathrm{il}_{5}$ \\
\hline EA 269 & fo t r por & \\
\hline EA 292 & if i if Ity & duné (33) \\
\hline EA 294 & है + गो हम & ty \\
\hline EA 297 & 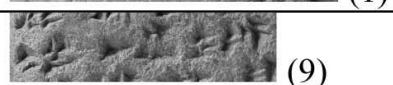 & \\
\hline
\end{tabular}

Plate 4 
EA 298

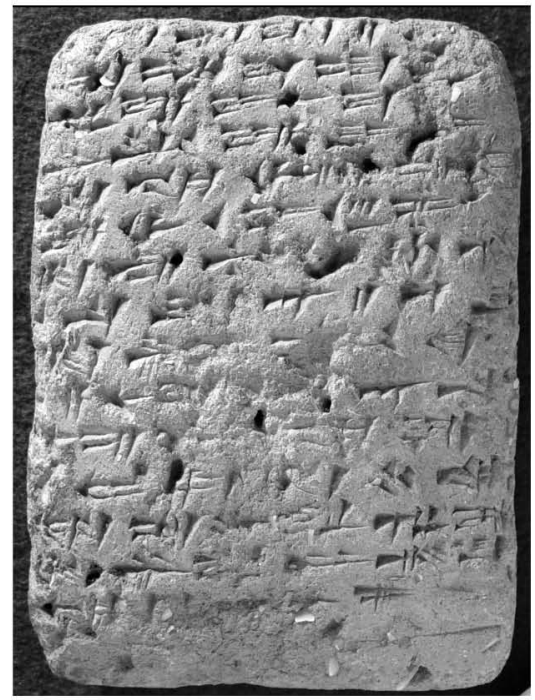

EA 378

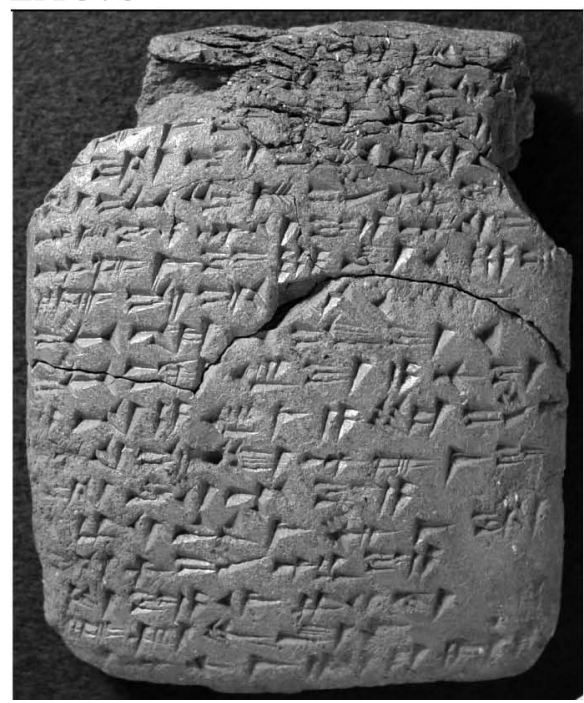

EA 299

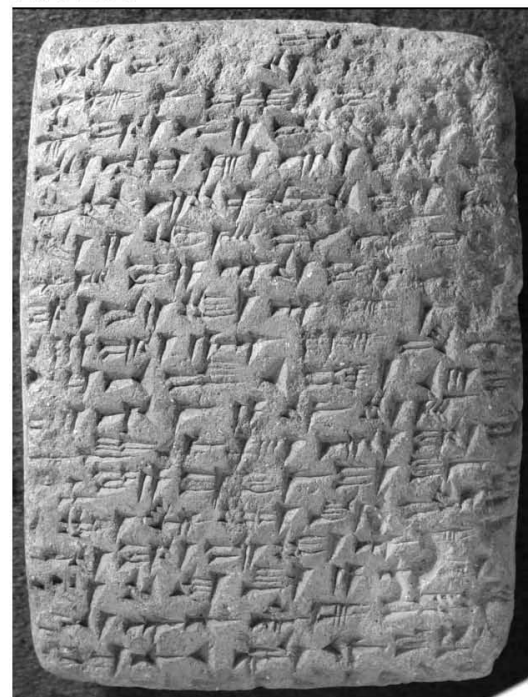

\section{EA 300}

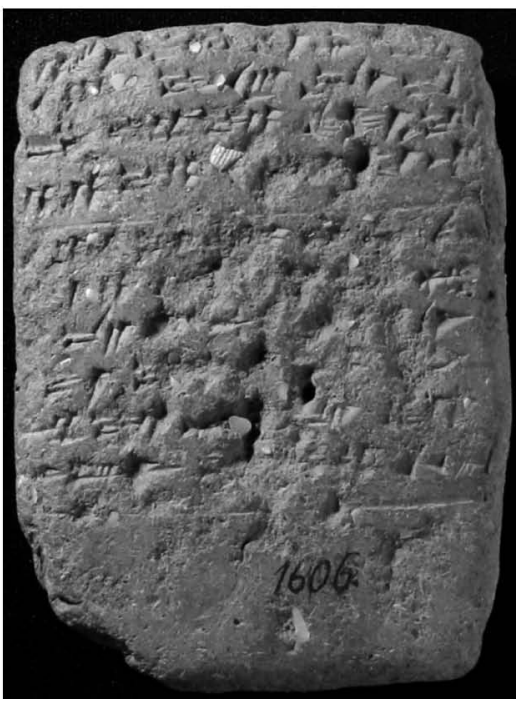

Plate 5 


\begin{tabular}{|c|c|}
\hline & 7-ta-a-an \\
\hline EA 298 & 17 \\
\hline EA 299 & $15 t$ \\
\hline
\end{tabular}

\begin{tabular}{|l|c|c|}
\hline & \multicolumn{2}{|c|}{ gìr.meš } \\
\hline EA 298 & (0) / & \\
\hline EA 299 & (9) & \\
\hline EA 378 & (7) & (5) \\
\hline
\end{tabular}

\begin{tabular}{|c|c|}
\hline & lu-ú iš-ta-ha-hai-in \\
\hline EA 378 & $1=12 \quad \rho^{2}+{ }_{(8)}$ \\
\hline EA 298 & 3 in \\
\hline
\end{tabular}

Plate 6

EA 297

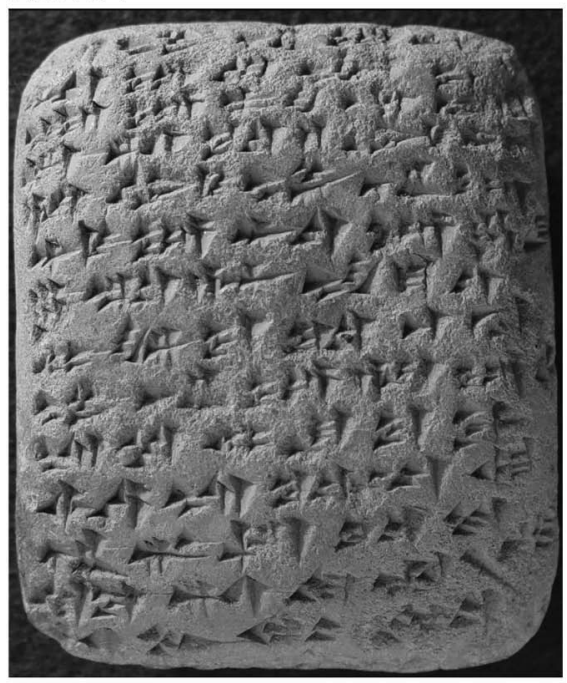

EA 294

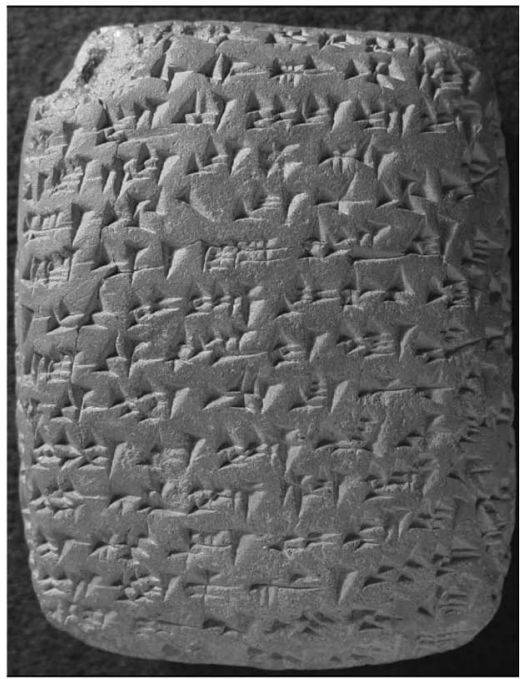

Plate 7 
EA 273

EA 271

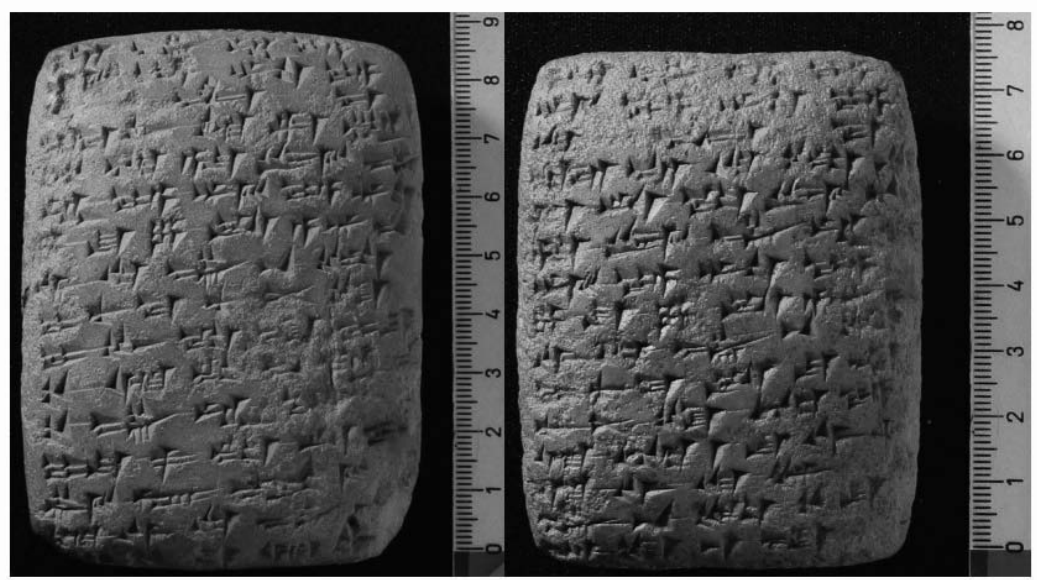

Plate 8

\section{EA 273}
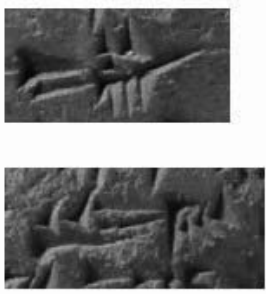

Gì.MES

LUGAL

TA

IA
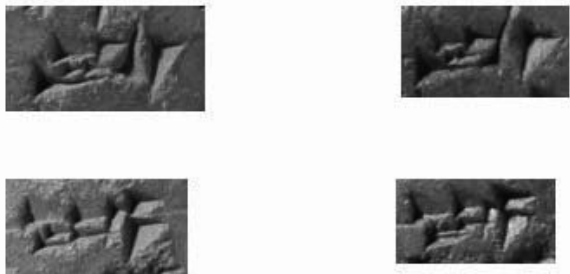

Plate 9 
EA 279

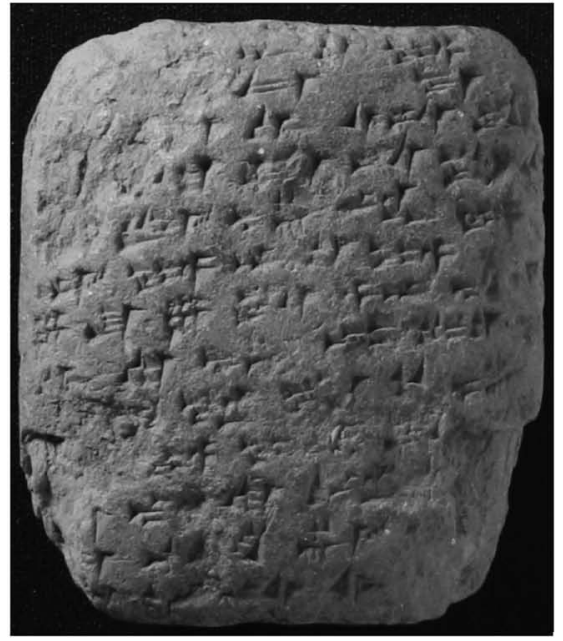

EA 278

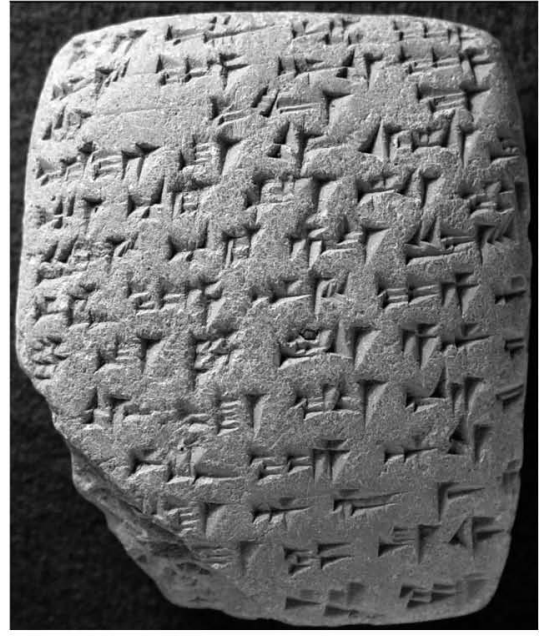

\section{EA 271}

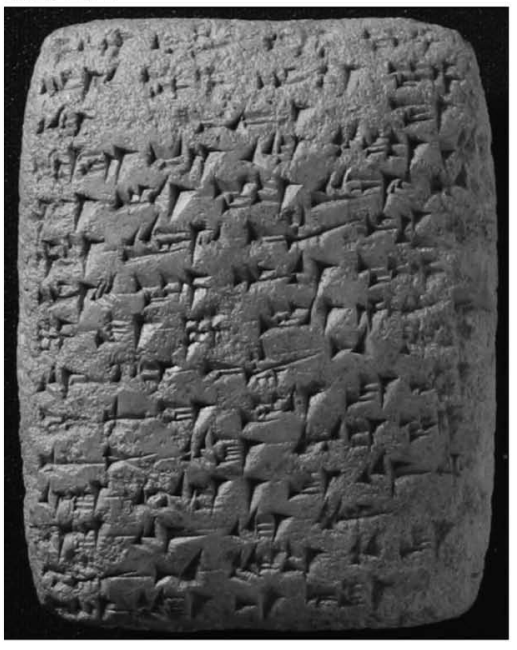

Plate 10 
EA 275

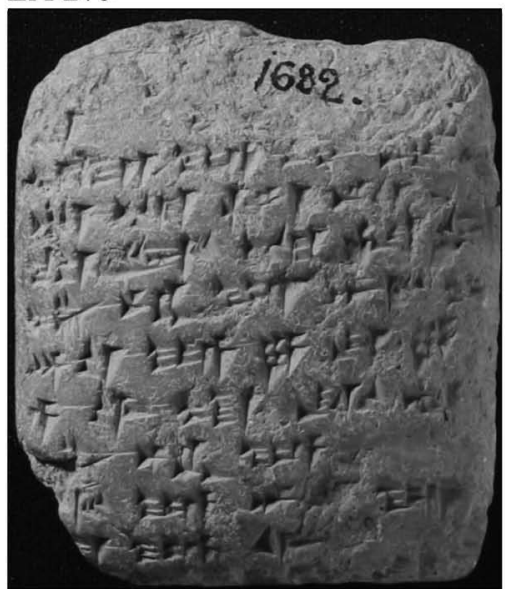

EA 277

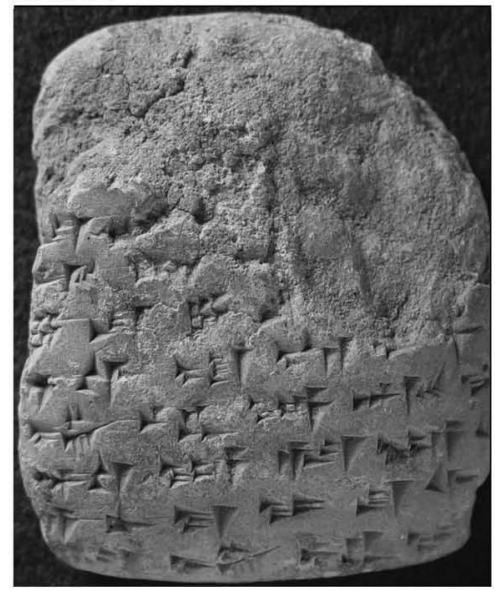

EA 276

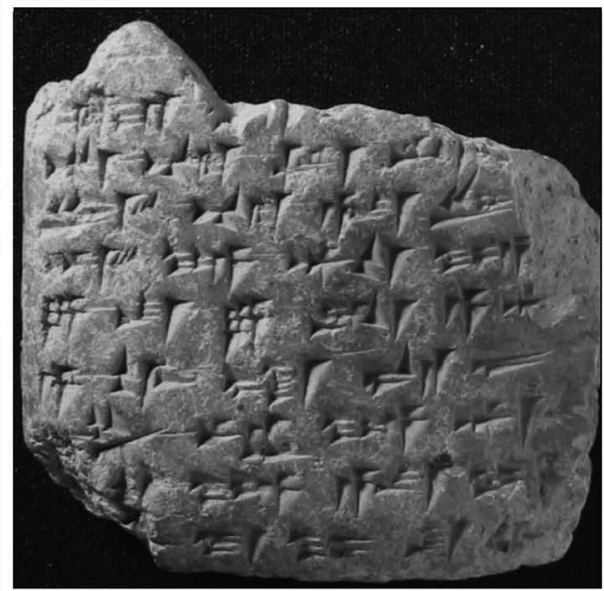

\section{EA 271}

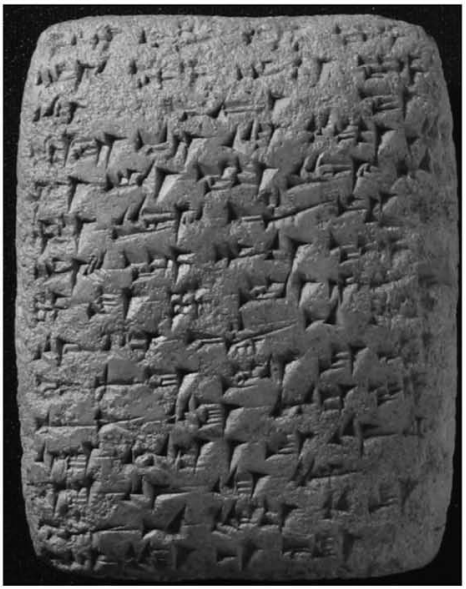

Plate 11 
EA 266

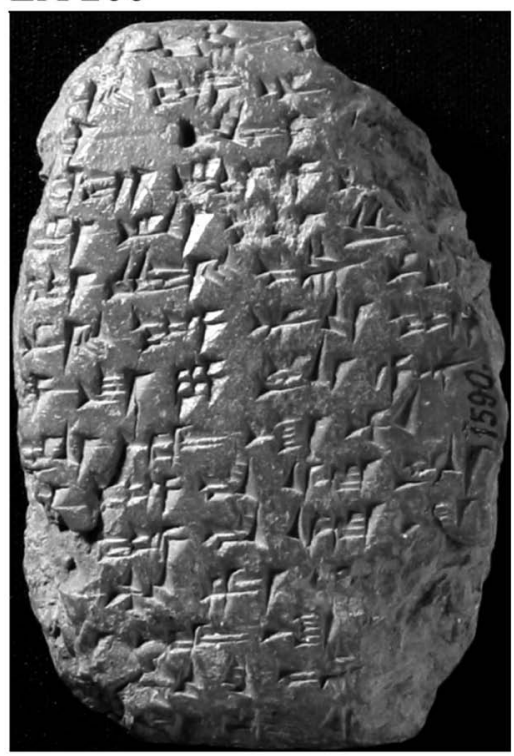

EA 273

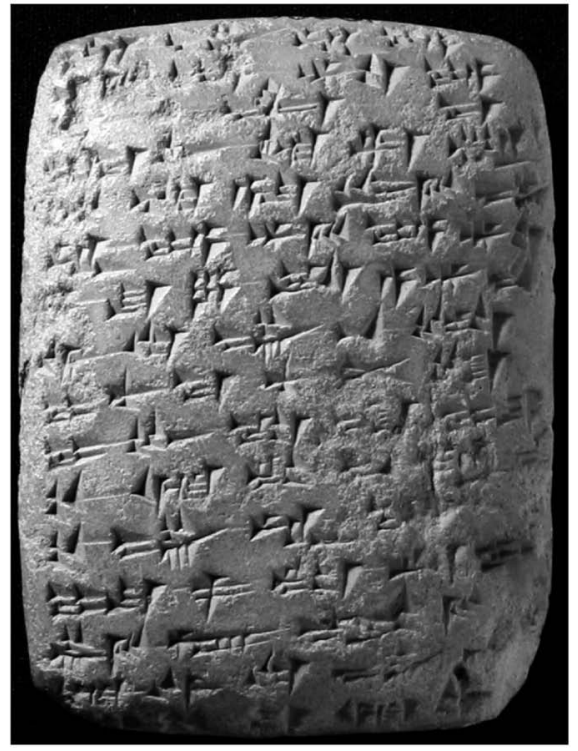

Plate 12 


\section{References}

Albright 1943

Artzi 1985

Belmonte 2001

Campbell 1964

Cohen 2009

von Dassow 2004

Donker van HeelHaring 2003

Driessen 2000

Gianto 1990

Gianto 2000

Goren 2000

Goren-FinkelsteinNa'aman 2002

Goren-FinkelsteinNa'aman 2003a

Goren-FinkelsteinNa'aman 2003b
Albright, W. F. A Tablet of the Amarna Age from Gezer. BASOR 92:28-30.

Artzi, P. The Present State of the Amarna Documents. Proceedings of the Ninth World Congress of Jewish Studies. Panel Sessions. Bible Studies and the Ancient Near East. Jerusalem. Pp. 3-16.

Belmonte, J. A. Die Orts- und Gewässernamen der Texte aus Syrien im 2.Jt. V. Chr. Wiesbaden.

Campbell, E. F., Jr. The Chronology of the Amarna Letters. With Special Reference to the Hypothetical Coregency of Amenophis III and Akhenaten. Baltimore.

Cohen, Y. The Scribes and Scholars of the City of Emar in the Late Bronze Age. Winona Lake.

von Dassow, E. Canaanite in Cuneiform. JAOS 124:641674.

Donker van Heel, K.; Haring, B. J. J. Writing in a Worksmen's Village. Scribal Practice in Ramesside Deir el-Medina. Leiden.

Driessen, J. The Scribes of the Room of the Chariot Tablets at Knossos. Interdisciplinary Approach to the Study of a Linear B Deposit. Salamanca.

Gianto, A. Word Order Variation in the Akkadian of Byblos. Roma.

Gianto, A. Amarna Akkadian as a Contact Language. van Lerberghe, K.; Voet, G. (eds.). Languages and Cultures in Contact. Leuven. Pp. 123-132.

Goren, Y. Provenance Study of the Cuneiform Texts from Hazor. IEJ 50:29-42.

Goren, Y.; Finkelstein, I.; Na'aman, N. The Seat of Three Disputed Canaanite Rulers according to Petrographic Investigation of the Amarna Tablets. Tel-Aviv 29:221-237.

Goren, Y.; Finkelstein, I.; Na'aman, N. The Expansion of the Kingdom of Amurru According to the Petrographic Investigation of the Amarna Tablets. BASOR 329:1-11.

Goren, Y.; Finkelstein, I.; Na'aman, N. The Location of Alashiya: New Evidence from Petrographic Investigation of Alashiyan Tablets from El-Amarna and Ugarit. AJA 107:233-255. 
Goren-Finkelstein-

Na'aman 2004

Hayes 1984

Hess 1993

Horowitz-Oshima

2004

Horowitz-OshimaSanders 2002

Horowitz-OshimaSanders 2006

Huehnergard-Izre'el (eds.). 2003

Ikeda 1992

Ikeda 1999

Izre'el 1978

Izre'el 1987

Izre'el 1991

Izre'el 1995

Izre'el 2003

Izre'el 2005

Janssen 1987

Janssen 2000

Katzenstein 1982
Goren, Y.; Finkelstein, I.; Na'aman, N. Inscribed in Clay. Provenance Study of the Amarna Tablets and Other Ancient Near Eastern Texts. Tel Aviv.

Hayes, J. L. Dialectal Variation in the Syntax of Coordination and Subordination in Western Akkadian of the el-Amarna Period. PhD. Diss. UCLA.

Hess, R. S. Amarna Personal Names. Winona Lake.

Horowitz, W.; Oshima, T. Cuneiform Tablets from Canaan in the Istanbul Arkeoloji Müzeleri. Colloquium Anatolicum 3:31-39.

Horowitz, W.; Oshima, T.; Sanders, S. A Bibliographical List of Cuneiform Inscriptions from Canaan, Palestine/ Philistia, and the Land of Israel. JAOS 122:753-766.

Horowitz, W.; Oshima, T.; Sanders, S. Cuneiform in Canaan. Cuneiform Sources from the Land of Israel in Ancient Times. Jerusalem.

Huehnergard, J.; Izre'el, Sh. (eds.). Moran, W. L. Amarna Studies. Collected Writings. Winona Lake.

Ikeda, J. Linguistic Identification of an Emar Scribe. Orient 28:37-40.

Ikeda, J. Scribes in Emar. Watanabe, K. (ed.). Priests and Officials in the Ancient Near East. Heidelberg. Pp. 163-185.

Izre'el, Sh. The Gezer Letters of the El-Amarna Archive. Linguistic Analysis. IOS 8:13-90.

Izre'el, Sh. Some Methodological Requisites for the Study of the Amarna Jargon. Notes on the Essence of That Language (http:/www.tau.ac.il/humanities/semitic/ eameth.html).

Izre'el, Sh. Amurru Akkadian: A Linguistic Study. Atlanta. Izre'el, Sh. The Amarna Glosses: Who Wrote What for Whom? IOS 15:101-122.

Izre'el, Sh. Canaanite Varieties in the Second Millennium BC: Can We Dispense with Anachronism? Orient 38:66-104.

Izre'el, Sh. Canaano-Akkadian. München. Janssen, J. J. On Style in Egyptian Handwriting. JEA 73:161-167.

Janssen, J. J. Idiosyncrasies in Late Ramesside Hieratic Writing. JEA 86:51-56.

Katzenstein, H. J. Gaza in the Egyptian Texts of the New Kingdom. JAOS 102:111-113. 
Katzenstein 1986

Knudtzon 1907-1915

Lacadena García-

Gallo 2000

Liverani 1998

Millard 1965

Moran 1975

Moran 1992

Na'aman 1997

Nougayrol 1955

Nougayrol 1968

Olivier 1967

Palaima 1988

Rainey 1996

Rainey 2003

Rainey-Notley 2006

Schroeder 1914

Smith 1998

Thureau-Dangin 1922

van der Toorn 2000

van der Westhuizen 1991

van der Westhuizen 1995
Katzenstein, H. J. Some Reflections Concerning ElAmarna 296. Ninth World Congress of Jewish Studies. A. The Period of the Bible. Jerusalem.

Knudtzon, J. A. Die El-Amarna-Tafeln. Leipzig.

Lacadena García-Gallo, A. Los escribas del Códice de Madrid: Metodología paleográfica. Revista Española de Antropología Americana 30:27-85.

Liverani, M. Le lettere di El-Amarna. Vol. 1. Le lettere dei "Piccoli Re". Brescia.

Millard, A. R. A Letter from the Ruler of Gezer. PEQ 97: 140-143.

Moran, W. L. The Syrian Scribe of the Jerusalem Amarna Letters. Goedicke, H.; Roberts, J. J. M. (eds.). Unity and Diversity. Essays in the History, Literature, and Religion of the Ancient Near East. Baltimore. Pp. 146-166 (= Huehnergard-Izre'el (eds.) 2003:249-274).

Moran, W. L. The Amarna Letters. Baltimore.

Na'aman, N. The Network of Canaanite Late Bronze Kingdoms and the City of Ashdod. UF 29:599-626.

Nougayrol, J. Le Palais Royal d'Ugarit. III. Paris.

Nougayrol, J. Ugaritica. V. Paris.

Olivier, J.-P. Les scribes de Cnossos. Essai de classement des archives d'un palais mycénien. Roma.

Palaima, Th. G. The Scribes of Pylos. Roma.

Rainey, A. F. Canaanite in the Amarna Tablets. 4 vols. Leiden.

Rainey, A. F. Some Amarna Collations. Ephial, I; BenTor, A.; Machinist, P. (eds.). Hayim and Miriam Tadmor Volume. Jerusalem. Pp. 192-202.

Rainey, A. F.; Notley, S. R. The Sacred Bridge. Carta's Atlas of the Biblical World. Jerusalem.

Schroeder, O. Die Tontafeln von El-Amarna (VS XI). Leipzig.

Smith, P. The Inflectional Morphology of the yvqtulVerb in the Shuwardata Amarna Letters (EA 278-284, 366). IOS 18:125-170.

Thureau-Dangin, F. Nouvelles lettres d'El-Amarna. $R A$ 19:91-108.

van der Toorn, K. Cuneiform Documents from Syria-Palestine. Texts, Scribes, and Schools. ZDPV 116:97-113.

van der Westhuizen, J. P. Morphology and Morphosyntax of the Verb in the Amqi Amarna Letters. JS 3:54-84.

van der Westhuizen, J. P. Word Order Variation of Verbal Sentences in Selected Gezer Amarna Letters. JS 7:1-15. 
van der Westhuizen 2000

van Soldt 2001a

van Soldt 2001b

van Soldt 2002

Vita 2000a

Vita 2000b

Vita 2002

Vita 2005

Vita 2006

Weber 1915 van der Westhuizen, J. P. Morphology and Morphosyntax of the Adjective as also Attributive and Predicative Constructions in the Amqi Amarna Letters. Van Lerberghe, K.; Voet, G. (eds.). Languages and Cultures in Contact. Leuven. Pp. 445-459.

van Soldt, W. H. Nahish-Shalmu, an Assyrian Scribe Working in the 'Southern Palace' at Ugarit. Van Soldt, W. H. et al. (eds.). Veenhof Anniversary Volume. Studies Presented to Klaas R. Veenhof on the Occasion of his SixtyFifth Birthday. Leiden. Pp. 429-444.

van Soldt, W. H. Studies on the sākinu-Official (1). UF 33:579-599.

van Soldt, W. H. Additions to "Studies on the sākinuOfficial (1). UF 33 (2001)". NABU 2002/74.

Vita, J.-P. La provenance de la lettre d'El-Amarna EA 308. Semitica 50:1-7.

Vita, J.-P. Das Gezer-Corpus von El-Amarna: Umfang und Schreiber. ZA 90:70-77.

Vita, J.-P. Der Schreiber der Amarnabriefe EA 221-223. SEL 19:33-36.

Vita, J.-P. Der biblische Ortsname Zaphon und die Amarnabriefe EA 273-274. UF 37:673-677.

Vita, J.-P. Anmerkungen zu einigen Amarnabriefen aus Kanaan. Del Olmo, G.; Feliu, Ll.; Millet, A. (eds.). Šapal tibnim mû illakū. Studies Presented to Joaquín Sanmartín on the Occasion of His 65th Birthday (AuOr Sup 22). Barcelona. Pp. 437-444.

Weber, O. Anmerkungen in the 2nd vol. of Knudtzon 1907-1915. Pp. 1009-1357. 